\title{
Lesbian Web Series - from Mainstream into Handpicked Audiences
}

\author{
Maya Schwartz Laufer* \\ Babes Bolyai University, Romania
}

Submission: May 07, 2017; Published: May 31, 2017

*Corresponding author: Maya Schwartz Laufer, Babes Bolyai University, str. Universitatii 7-9, Cluj-Napoca 400084, Romania, Tel: 97236911168; Email: mayaschwartz@gmail.com

\begin{abstract}
This article is based on my Ph.D. thesis and it aims to show the integration of Lesbians in a western context in the Internet; as web series, addressed to the Lesbian community and its diversities. Lesbian relationships were documented as early as in 1870. The term was interchangeable with "Sapphist" and "Sapphism" around the turn of the 20th century. Sapphism is taken from the Greek Lesbian lyric poet Sappho, who was born on the island of Lesbos. The Alexandrians included her in their list of the nine lyric poets. Her birth was sometime between 630 and $612 \mathrm{BC}$, and it is said that she died around $570 \mathrm{BC}$, but little is known for certain about her life. The bulk of her poetry, which was well - known and greatly admired throughout antiquity, has been lost, but her immense reputation has endured through surviving fragments. The use of "Lesbian" in medical literature became prominent; by 1925 the word was recorded as a noun to mean the female equivalent of a sodomite. The development of medical knowledge was a significant factor in further connotations of the term. In the middle of the 19th century, medical writers attempted to establish ways to identify male homosexuality, which was considered a significant social problem in most Western societies. In categorizing behavior that indicated what was referred to as "inversion" by German sexologist Magnus Hirschfeld (1897), researchers determined what was normal sexual behavior for men and women, and therefore to what extent men and women varied from the "perfect male sexual type" and the "perfect female sexual type".
\end{abstract}

Keywords: Lesbian mainstreamism; Stereotypes; Internet; Web series; Butch \& femme; Evolution; Queer-theory; LGBT

\section{Introduction}

According to Goodloe [1] in the past two decades, the dominant form of feminist discourse has attempted to liberate Lesbian identity from patriarchal control, compel its own identity politics on the Lesbian community, resulting those Lesbians whose behaviors did not correlate to the feminist agenda being oppressed twice; once by the dominant patriarchal culture and again by the women's liberation movement. This is perhaps most obvious in the feminist critique of role playing among Lesbians, which is considered by dominant feminist discourse to be an obstacle to a woman's true identity. While some Gay or Lesbian couples may comprise a butch-identified individual and a femmeidentified individual, not all gays or Lesbians identify as "Butch" or "Femme". The word femme - is French and means woman; the word Butch means - "rough boy" (tough kid). This Division was accepted in the 1930's. Femmes were dressed in feminine clothes, high heels and wore makeup, and Butches dressed in suits and hats and looked very manly. In the 1970's, feminists claimed that it was a submission to oppressive male perception. American historian Lillian Federman claims that this created an androgyny and a butch look (male) for women, who are not necessarily Lesbians. The criticism claims that these identities try to replicate heterosexuality by setting one male and one female, and there is no need to imitate heterosexuality in order to live happily. Most research in this area focused on traditional culture in women's genres, such as soap operas, novels, women's journals and female studies such as [2-5] Radway (1984). These female scholars have argued that women's attitude towards popular texts, stem from the awareness of self-reflection. Furthermore, it is assumed that these texts and women's ideology fight against the patriarchal and capitalist hegemony ideology while being positioned within it. Buckingham [6] emphasized the ways in which complex interaction with texts contributes to identities, including gender-specific word identities. As a general rule, therefore, communication is taken, as of reception, in which the process of incessant construction of woman's identity occurs. The process by which, according to Simone de Beauvoir "one is not born a woman, but becomes one" (De Beauvoir, 1949).

Media influence is similar everywhere, the sender controls the process. The theory of socialization deals with processes by which the individual learns to function in society. This is as 
slow and almost constant process, in which a person acquires key norms and values of the society around them. Henslin [7] Selective exposure, where a recipient decides what he is exposed to for various reasons and the perception is selective, in which different people are exposed to the same content, but interpret them in different ways according to their worldview (framing) Raymond [8] used the term "symbolic annihilation" to describe the invisibility of Gays and Lesbians in mass media; if, as Gross suggested, representation attaches to power, then that invisibility evidences the powerlessness of the queer community. Even media studies sensitive to portrayals of minorities in the media (e.g., Greenberg [9]) tended to focus mostly on ethnic and racial minorities and to ignore sexual orientation as a defining aspect of identity. According to Gross, Gays and Lesbians tend to be even more isolated and invisible than members of racial and ethnic minorities and are therefore probably the least permitted to speak for themselves in the mass media." However, this was in 1995, and since then, as not only my research shows, but is clearly visible to us all in television shows around the world, LGBT characters are everywhere.

There are not too many mainstream television shows with Lesbian main characters, but there is no shortage of online web series and short films. Many of them are independently produced and rely on viewer contributions to keep production going. Most shows are in a format called "Webisodes" - each episode lasts between six and fifteen minutes. Most web series come from the US, such as Exes \& Hoes [10] an American and Canadian series launched on Logo (Logo TV is a network that celebrates one-ofa-kind personalities, entertaining a social, savvy audience of gay trendsetters). The show was released on October 8, 2007, and Showcase in Canada, Showcase. The show focuses on the dating life of Jennifer (Michelle Paradise), a Lesbian documentary filmmaker with a vivid fantasy life and a floundering career. Jennifer is looking for Ms. Right but must navigate the rules of Lesbian dating life, most of which she learns the hard way. "GIRLTRASH!" (2007) Best friends and literal partners in crime, Tyler (Michelle Lombardo) and Daisy (Lisa Rieffel) find themselves in the midst of a gang war, which complicates their already edgy lifestyle. Whether Apples [11] comes from cultural differences or general quirkiness is debatable, following the lives of a group of Lesbian students, one of whom is obsessed with her stuffed cat, Chichi. Chica Busca Chica [12] was created by Sonia Sebastian. This award-winning series from Spain is a titillating parade of scoundrels, both gay and straight. [2] tells of 16 year old Vivian, the daughter of a NYC firefighter, who has no choice but to leave the city with her dad after health problems he suffered, trying to save people on September 11th force him to retire. 3 Way [13] is about an ageing soap actress Siobhan (Maeve Quinlan) who finds herself newly divorced and taking in her Lesbian best friend only to find that she has invited a world of dyke drama into her home. "Time Traveling Lesbian" (2008) in which comedian Rebecca Drysdale plays herself in a silly series in which a jaded video rental clerk discovers she is the only one in the universe who has a hope of rescuing the time - space continuum. Venice [14] is a series co-created by Crystal Chappell and Kim Turrisi and focuses on the life of Gina Brogno, a single, gay, self-made interior designer, living and working in Venice Beach, California. The plot follows Gina's experiences in connection to her various love interests. Fletcher [15] is about private investigator B.J. Fletcher (Lindy Zucker) and her trusty assistant Georgia Drew (Dana Puddicombe) The Canadian series follows the dynamic duo as they grapple with everything from running surveillance to going undercover. Seeking Simone [16] is a Canadian show, starring actress and co-creator Renée Olbert. The series follows Simone, a Lesbian actress (the star of the fake television series CSIS: Forensic SWAT) as she attempts to find love in her new home, Toronto. [14] is about a married Lesbian couple who are both therapists and coauthors of a No. 1 book on sustaining a successful marriage and now find themselves on the verge of a divorce and under surveillance by a documentary film crew. Far out [17] created by Faye Hughes, tells the story of a group of Lesbian friends living in London, featuring ordinary Lesbians in realistic situations. Girl girl scene [18] is based on the lives and loves of a group of young Lesbians in mid America and shows an honest reflection of today's young Lesbian culture. "The Lovers and Friends Show", (2010) recognizes one group in the gay community that is too often overlooked - Lesbians of color. Featuring an entirely African American and Latina cast, the show takes the characters through a typical drama - filled barrage of romantic issues. "TH3M", (2010) was created by Tye Green and began as a TV pilot that works as a short film and as a web series. It tells the story of several friends (most of them African American) living, loving and working through their issues. "Out with Dad", (2010) is a Canadian award-winning drama web series, officially endorsed by PFLAG Canada. "Girl play", (2012) is a New Orleans-based show which fills the void of leading fictional black Lesbian characters with masculinecentered or identified women. "Frequency", (2012) is a Sci-fi Lesbian web series, created by Piper Kessler. "The Throwaways", (2012) is a tellofilms.com production, a web site that produces and airs only Lesbian themed content. It costs money to watch full episodes, but the money is given to the creators of the shows. "I Hate Tommy Finch", (2012) is a one-act, two-woman, Lesbian play about the relationship between The newest show from Netflix is called: "Orange is the New Black", created by Jenji Kohan (creator of "Weeds") shows a privileged white woman named Piper Chapman forced to serve time in prison. She leaves behind her beloved fiancé, only to end up in the same facility as her one- time Lesbian lover, the same woman whose actions led to Piper's incarceration.

\section{Web- Categorizing Various Relevant Series 2006- 2014}

While looking into the various all-Lesbian web series, I selected to examine in my research (naturally this media is the rather recent and I have started documenting from 2006). 
I decided to include 20 web series. Once again, most of the material is made in the United States, because subtitles very unusual when it comes to internet programs. I have divided them into eight categories:
a. Year of airing,
b. Country,
c. Type of show,

\section{These are the web series I chose to examine}

Table 1: Web series variables.

\begin{tabular}{|c|c|c|c|c|c|c|c|c|}
\hline Name & Year & Country & Type & Race & Nagative & $\begin{array}{l}\text { Butch \& } \\
\text { Femme }\end{array}$ & Environment & $\begin{array}{c}\text { Youtube } \\
\text { exposure }\end{array}$ \\
\hline Exes \& Ohs & 2006 & USA & Drama & White & Positive & $\mathrm{N}$ & Good & Minimal \\
\hline Girltrash & 2007 & USA & Dramedy & White & Positive & $\mathrm{N}$ & Good & Good \\
\hline Apples & 2007 & Spain & Drama & Spanish & Positive & $\mathrm{N}$ & Good & Good \\
\hline $\begin{array}{c}\text { Anyone but } \\
\text { Me }\end{array}$ & 2008 & USA & Drama & White & Positive & $\mathrm{N}$ & Good & Excellent \\
\hline $\begin{array}{c}\text { Time } \\
\text { Traveling } \\
\text { Lesbian }\end{array}$ & 2008 & USA & Comedy & white & Positive & Y & Good & Minimal \\
\hline Feed & 2008 & USA & Drama & White & Positive & $\mathrm{N}$ & Good & Good \\
\hline way & 2008 & USA & Comedy & White & Positive & $\mathrm{N}$ & Good & Excellent \\
\hline $\begin{array}{l}\text { Chica Busca } \\
\text { Chica }\end{array}$ & 2008 & Spain & Drama & Spanish & Positive & $\mathrm{N}$ & Good & Excellent \\
\hline Venice & 2009 & USA & Drama & White & Positive & $\mathrm{N}$ & Good & Excellent \\
\hline B.J Fletcher & 2009 & Canada & $\begin{array}{l}\text { Action } \\
\text { Comedy }\end{array}$ & White & Positive & $\mathrm{Y}$ & Good & Minimal \\
\hline $\begin{array}{l}\text { Seeking } \\
\text { Simone }\end{array}$ & 2009 & Canada & Comedy & White & Positive & $\mathrm{N}$ & Good & Good \\
\hline Far Out & 2009 & UK & Drama & Mixed & Positive & $\mathrm{Y}$ & Good & Mininal \\
\hline $\begin{array}{l}\text { We have to } \\
\text { Stop Now }\end{array}$ & 2010 & USA & Drama & White & Positive & $\mathrm{N}$ & good & Good \\
\hline GirlGirl Scene & 2010 & USA & Drama & White & Positive & $\mathrm{N}$ & Good & Good \\
\hline Out with Dad & 2010 & Canada & Drama & White & Positive & Y & Good & Good \\
\hline TH3M & 2010 & USA & Drama & mixed & Positive & $\mathrm{Y}$ & Good & Good \\
\hline $\begin{array}{c}\text { The Lovers } \\
\text { and friends } \\
\text { show }\end{array}$ & 2010 & USA & Drama & Black & Positive & Y & Good & Good \\
\hline Frequency & 2012 & USA & Sci Fi & White & Positive & $\mathrm{Y}$ & Good & Minimal \\
\hline $\begin{array}{c}\text { The } \\
\text { Throwaways }\end{array}$ & 2012 & USA & Drama & White & Positive & Y & Bad & Minimal \\
\hline $\begin{array}{l}\text { I Hate Tommy } \\
\text { Finch }\end{array}$ & 2012 & USA & Drama & White & Positive & $\mathrm{N}$ & Good & Minimal \\
\hline Easy Abby & 2013 & Canada & Dramedy & White & Positive & $\mathrm{N}$ & Good & Good \\
\hline The Glass & 2013 & Russia & Drama & White & Positive & Y & Good & Minimal \\
\hline $\begin{array}{c}\text { Starting from } \\
\text { now }\end{array}$ & 2014 - now & USA & Drama & White & Positive & Y & Both & Good \\
\hline $\begin{array}{l}\text { Producing } \\
\text { Juliet }\end{array}$ & 2015 & USA & Drama & White & Positive & Y & Good & Good \\
\hline Lily Fever & 2015 & Korea & Drama & Asian & Positive & $\mathrm{Y}$ & Good & Minimal \\
\hline Designated & 2016 & US & Drama & Mixed & Positive & $\mathrm{Y}$ & Good & Minimal \\
\hline $\begin{array}{l}\text { The other } \\
\text { love story }\end{array}$ & 2016 & India & Drama & Indian & Positive & Y & Good & Minimal \\
\hline
\end{tabular}


Exes \& Ohs, Girltrash, Apples, Anyone but Me, Time Traveling Lesbian, Feed, 3way Chica Busca Chica, Venice, B.J Fletcher, Seeking Simone, Far Out, We have to Stop Now, Girl Girl Scene, Out with Dad, TH3M, Lovers \& Friends, Frequency. The Throwaways, I Hate Tomy Finch, Orange is the New Black, Easy Abby, The Glass, Starting from now, Producing Julia, Lily fever, Designated, The other love story (Table 1).

\section{Findings}

75\% were American productions, 5\% British, Russian, Indian and Korean $10 \%$ from Spain and 10\% Canadian. $85 \%$ of the web series were considered Drama 5\% Sci Fi and only 10\% Comedy. 70\% featured White actresses, 10\% Homogeneous, $10 \%$ Spanish -European, 5\% Latino and 5\% Black. Only 35\% had a butch and femme categorization of their main characters, and $95 \%$ presented lesbians in a positive way. In $95 \%$ of the shows the close environment of the main character accepted or reacted well to them being gay. And finally, $35 \%$ had minimal exposure, $45 \%$ had good exposure and only $20 \%$ had excellent exposure.

In the middle of the new Millennium, a new player came along and changed our media consumption habits -the Internet. Web series popped up like mushrooms after the rain all over the western world, connecting to audiences at their own convenience and ratings were measured by the millions (unlike film and television, which are measured in sample groups) The entire concept of our media consumption has altered because of that and creating a web series is easier and much cheaper than creating a feature film or a Television series. Everyone can find their own point of interest especially since Netflix and Amazon snatched the glory from Television networks and began producing web series for less money and with larger variety. No middleman is required; episodes can be as long or as short as one likes (unlike film or Television) and the variety out there is astonishing; there is something for everyone.

\section{References}

1. Goodloe A (1993) Lesbian Identity and the Politics of Butch- Femme Roles.

2. Ang I (1985) Anyone But Me (2009-2012) written and directed by Tina Cesa Ward

3. Currie DH (1997) Decoding femininity: Advertisements and their teenage readers. Gender \& Society 11(4): 453-477.

4. Frazer E (1987) Teenage Girls Reading Jackie, Media, Culture, and Society (GLBTQ- encyclopedia of gay, lesbian, bisexual, transgender and queer culture.

5. Modleski T (1984) Loving with a Vengeance: Mass-Produced Fantasies for Women. London: Methuen.

6. Buckingham D (1993) Changing Literacies: Media Education and Modern Culture.

7. Henslin, James M (1922) 1999 Sociology: A Down-To-Earth Approach, ( $4^{\text {th }}$ edn) Boston: Allyn and Bacon Hirshfeld, M.

8. Gross L (1995) Out of the mainstream: Sexual minorities and the mass media. In: Dines G \& Humez JM (Eds.), Gender, race and class in media: A text-reader, Thousand Oaks, CA: Sage, pp. 61-69.

9. Greenberg BS (1986) Minorities and the mass media. In: Bryant J \& Zillmann D (Eds.), Perspectives on Media Effects. Hillsdale, NJ: Lawrence Erlbaum, pp. 165-188.

10. Exes, Ohs, (2006) written by Michelle Paradise, directed by: Gary Harvey, James Genn, Mina Shum. Girl Trash, 2008-2009,

11. Apples (2007) written by Olga Marti, directed by Alfonso Diaz.

12. Chica Busca Chica (2008).

13. 3Way (2008) Paige Bernhardt.

14. Venice (2009) created by Crystal Chappel and Kim Turrisi We have to stop now, 2009, Ann Noble.

15. Fletcher BJ (2009) Private Eye.

16. Seeking Simone, Canada, (2009-2011) written by Rosemary Rowe, directed by Naomi Jaye and Lisa Hayes.

17. Angela Robinson Far Out (2009) created by Faye Hughes FEED, (2008) created by Mel Robertso.

18. Girl Girl Scene (2010) created by Tucky.

\begin{tabular}{l} 
Your next submission with Juniper Publishers \\
will reach you the below assets \\
- Quality Editorial service \\
- Swift Peer Review \\
- Reprints availability \\
- E-prints Service \\
- Manuscript Podcast for convenient understanding \\
- Global attainment for your research \\
- Manuscript accessibility in different formats \\
( Pdf, E-pub, Full Text, Audio) \\
- Unceasing customer service \\
Track the below URL for one-step submission \\
https://juniperpublishers.com/online-submission.php \\
\hline
\end{tabular}

